\section{3 | How editors choose which human rights news to cover: a case study of Mexican newspapers}

\author{
ELLA MCPHERSON
}

\section{Introduction}

While much of this book is focused on the effects of human rights coverage on mobilization, we must remember that this coverage is not produced in a vacuum. During the day-to-day practice of journalism, members of the media are affected by a variety of influences that determine not only what information they choose to report and how they report it, but also what information they choose to ignore. These choices - or, as the case may be, commands - shape the human rights information transmitted by the media, and, if we presume that this information has an effect on its audiences, shape mobilization as well. It is therefore very important to understand the influences on human rights reporting.

Through a case study of human rights reporting at Mexican newspapers, I aim to provide an overview of what journalists are trying to do when they cover human rights stories and how these aims interact with overt influences on journalism, such as economic considerations and political pressures, to produce human rights news. To do this, I have developed a framework for thinking about how the headlines are plucked from the informational ether of every news day. Specifically, information is assessed against basic criteria of newsworthiness. Of that which is considered newsworthy, the more a particular piece of information is in line with a newspaper's journalistic, economic, and political aims relative to other bits of information, the more likely it is to be published. I explain these assessment categories in turn in this chapter, describing what kinds of human rights news survive this winnowing at Mexican newspapers.

\section{Background}

This chapter draws on a media ethnography conducted in Mexico in 2006 in the time preceding and following Mexico's first presidential election since what many consider to be its transition to democracy. ${ }^{1} \mathrm{~A}$ watershed moment in this transition was the victory of the right-leaning opposition, the National Action Party (PAN), in the 2000 presidential election, ending the more than seven-decade reign of the Institutionalized Revolutionary Party (PRI). Mexico's media were instrumental in this political upheaval, not least because of reporting that challenged the government, a manifestation of particular news outlets' increasing economic and editorial independence from the state (Hughes 2006; Lawson 2002).

This independent sector of the media emerged as a core group of media leaders became disillusioned with the PRI, particularly following what is known as the 1976 Tlateloco Massacre, a violent clash between protesting students and the police that left hundreds of protestors dead. Until this point, the media largely sought a cozy, cashfor-coverage relationship with the government. In the days following this event, newspapers loyal to the PRI faithfully disseminated official government accounts of a few dozen killed, even though the word on the street was that the death toll ran into the hundreds. People took to the avenues in protest at the PRI's brutal repression, and one of their chants was 'Prensa vendida!' ('Sell-out press') (Rodríguez Castañeda 1993, 120).

This novel, fierce public criticism of the press shook journalists (Lawson 2002). A core group, whom Hughes (2006) calls 'change agents,' all print journalists, decided that their journalism should break from Mexican tradition by focusing on democracy-enhancing journalistic aims and advocating a more watchdog stance. Some of these change agents were newspaper owners who implemented top-down change, some were groups of reporters who advocated change from below, and sometimes change spread laterally as staff left newspapers committed to the traditional journalistic model to join those more open to change. Democratic journalistic aims gradually diffused among these publications via training, the establishment of educational and reflexive forums, and the development of codes of ethics (Hughes 2003). As public demand burgeoned for the independent information published by these more autonomous newspapers and news magazines, change agents discovered that financial survival was possible without the help of the state. I call their newspapers 'market oriented' because of their financial dependence on audiences and advertisers rather than on financial-informational contracts with the state.

Despite Mexico's advances on the national level for democratization in general and democratic journalism in particular, the context in which regional newspapers operated in Mexico's poorest states was 
little different at the time of my research than during the heyday of the PRI. In 2006, the governments of Mexico's poorest states, Chiapas and Oaxaca, were all-powerful; they dominated the political and economic spheres, the latter through policies and favors, and because the private sectors of these states were relatively undeveloped - making the state the primary source of advertising revenue. Politics in Chiapas and Oaxaca were personalistic, with governors at the pinnacles of local political power, and constituents often forged allegiances directly with them rather than with their parties. Loyalty was rewarded, while dissidence was suppressed or punished. With respect to the media, these carrot-and-stick tactics included payment for commissioned articles, the criminalization of libel and slander, and the very real threat of physical intimidation. For example, a matter of days after I left Oaxaca, gunmen burst into one newspaper's newsroom and fired shots, injuring two reporters. As much as journalists might have liked to practice democratic journalism, events like this - in concert with the 'muzzle law, as the defamation law is known in Chiapas, and with the fact that newspapers could find very few private-sector advertisers in these poor states - often silenced the watchdog at these 'state-oriented' newspapers - though not in all cases, as we will see later.

It is common, perhaps even compulsory, for both state-oriented and market-oriented newspapers in Mexico to have a human rights beat. ${ }^{2}$ Although human rights reporters now cover human rights at large, including the activities of human rights non-governmental organizations (NGOs), journalists told me that their positions were originally created to cover Mexico's national and state human rights commissions. These semi-autonomous, government-funded commissions were established during the negotiations for the North American Free Trade Agreement, largely as a way to allay US concerns about the Mexican government's human rights record (Sikkink 1993). They monitor human rights situations in Mexico by investigating citizens' complaints about human rights infractions committed by state institutions. If a commission finds an institution to have violated a human right, it will issue that institution with non-binding recommendations for restitution. Correspondingly, human rights in Mexico are conceptualized as part of the relationship between the citizenry and the government. This means that human rights in Mexico is very much an issue of domestic importance; the critical lens is focused closely on the behavior of the Mexican state toward its citizenry, rather than aimed abroad, as is so often the case in Western nations. It also means that only state individuals and institutions can be categorized as violators of human rights. The same violation committed by a non-governmental civilian is classified as a crime, a category that has its own police beat at Mexican newspapers. Human rights reporting is therefore a relatively new but quite established part of Mexican journalism, categorized under political or society news (the latter in the sociologists' rather than the gossip columnists' sense of the word) and focused on state performance with respect to human rights. Some journalists measured this according to the Western idea of human rights, drawing on the UN's concept, while others preferred a more individualistic understanding of what they thought human rights should be in the particular context of Mexico.

\section{A framework for understanding news selection}

Figure 3.1 is a framework intended to illustrate how news selection occurs, though it necessarily simplifies this process drastically. This model clarifies the influences on the news arising from journalists' aims, tempered by contextual pressures. Of course, the practice of journalism may also be swayed by a whole host of more subtle influences, such as the social organization of the newsroom or cultural norms, which are insidious because they are largely structural (see McPherson 2010 for an analysis of these influences with respect to human rights reporting at Mexican newspapers). But this model plots the overt aspects of the determination of news - in other words, those attributable more to agency than to structure. This news selection

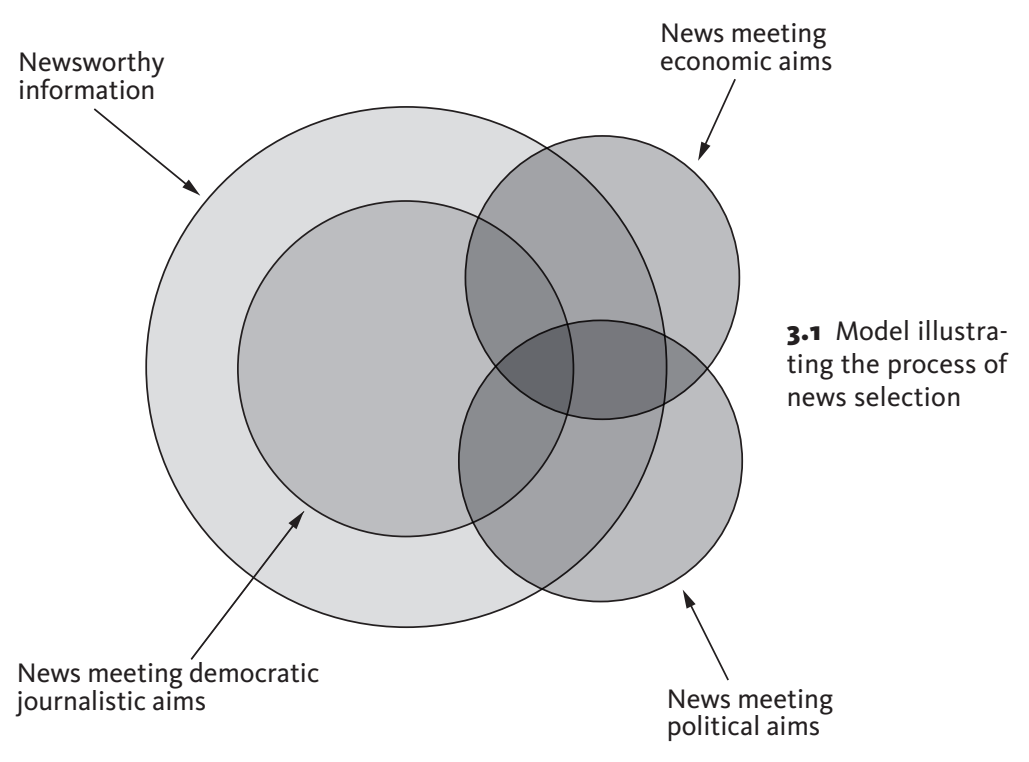


framework exists on a newsroom level, but each journalist also has his or her own version that may or may not align with that of the newsroom. In this section, I describe this model in broad strokes, whereas in the subsequent sections I describe more specifically the main criteria of news selection with particular reference to human rights reporting at Mexican newspapers - namely, what is considered newsworthy with respect to human rights and how human rights coverage relates to these newspapers' journalistic, economic, and political aims.

The model depicts various circumscriptions of information. The informational plane in which it is set is not all of the information in the world, but rather the information that reaches journalists. This is not a neutral process. This information depends on where journalists go, whom they know, and - crucially - which sources of information have the requisite resources to access and gain the attention of the newsroom. The resource in question might be social capital, held particularly, for example, by the communications officer of a human rights NGO who has, over time, become friends with the human rights reporter, or by the political movers and shakers who regularly lunch with editors to swap stories. It may be financial capital, reflected in the ability to attract journalists to press conferences with fax and email invitations requiring access to communication technologies - certainly not a given for Mexican human rights organizations. It may take the form of what Bourdieu (2007) calls symbolic capital, namely reputational characteristics such as credibility. For example, Mexican human rights NGOs struggle to build up their reserves of credibility, as they are not infrequently the targets of discrediting discourses levied by those they have accused of human rights violations. As a result, they can have trouble convincing journalists to consider their information (McPherson 2010).

For the print versions of Mexican dailies, the plane of available information has clear time delimitations, in that it consists of the information that crosses journalists' paths in a particular day. Even on the slowest of news days, this plane exceeds the space, in terms of column inches, and time, in terms of man-hours of reporting, that a newspaper can devote to news. Journalists therefore continuously rely on criteria to circumscribe this information so that their resources are deployed against the most valuable information - such as when editors assign or reporters choose stories, when reporters determine the direction of their daily beat, or when editors select headlines.

Figure 3.1 depicts the most relevant criteria considered for human rights news in Mexico: newsworthiness, journalistic aims, political aims, and economic aims. Of course, other criteria exist depending on the newspaper or the topic - goriness, for example, for Mexico's nota roja ('red news') crime tabloids, or safety, for reporting on the drug war. In the figure, the more important the criterion, the darker the shading of the sphere (in this version, each set of aims is depicted as equally important), and the darker the shading of the area in question, whether or not arising from sphere overlaps, the more likely it is that the information populating it will be published. The broader the criterion, the bigger its sphere. The broadest criterion newsworthiness - is, as I describe in the next section, a hard-to-define concept - almost a sixth sense. It refers to, for example, the scale of the incident that the information describes or to the impact and/or exclusivity of the information. With some exceptions that I explain later in this section, information that appears in print is by definition newsworthy. Journalists do not, however, judge information on its newsworthiness alone. Much of the news they choose also serves ulterior aims - the conglomeration of which can be referred to as a newspaper's editorial line.

Journalistic aims refer to the role that journalists see their media as ideally playing in society. The dominant academic theory and the perspective of many practitioners mandate that journalism supports democracy and therefore journalists pursue democratic journalistic aims such as supporting pluralism and holding the state to account. Not all journalists are interested in democratic journalism, however - such as the owners of what are called 'ghost newspapers' in Mexico. These newspapers gather dust, unsold, on news stands, as they make money more on what they do not print than on what they do; these newspapers unearth scandalous gossip about the political and economic elite and then blackmail them, demanding payment to prevent publication. For ghost newspapers, as well as for some state-oriented newspapers, the journalistic aims criterion is non-existent. Not all reporters share their bosses' approach to classifying news, however - a clash that may lead to the subversive news dissemination tactics I describe later.

This leads us to economic aims. Most newspapers are also businesses, although in theory a Chinese wall exists between the business and information departments of media institutions. At many Mexican newspapers, however, information-gathering is very much influenced by the need to turn a profit in tough times - if not outright determined by owners' financial goals. The more important money is, the more influential the sphere of economic aims is in the choice of news. Another criterion is political aims, which again vary according to a newspaper's position on the political spectrum and its owner's 
personal and partisan allegiances. These economic and political aims are necessarily newspapers' responses to their economic and political contexts, as ignoring them could risk their very survival.

The diagram depicts these three criteria of aims as overlapping with each other and with the criterion of newsworthiness. The sphere of information that meets a newspaper's journalistic aims generally coincides in its entirety with the sphere of newsworthiness by dint of the fact that if the information is important for democracy, it is newsworthy. ${ }^{3}$ The journalistic sphere overlaps with the political sphere when information that supports democracy also happens to support a newspaper's political proclivities. It overlaps with the economic sphere when it also meets reader or advertiser demands. On rarer occasions, information falls into all three categories. For example, Mexico's national left-leaning newspaper, La Jornada, conducted extensive and agendasetting investigations into the human rights violations committed under conservative Mexican president Vicente Fox's administration during the May 2006 clash between street vendors and police in the town of San Salvador Atenco. These investigations met La Jornada's journalistic aims of 'criticizing power,' in the words of one journalist. Although most of $L a$ Jornada's journalists said they were unconcerned with economic aims, one editor told me that his newspaper always grows in times of national crisis such as the Atenco situation because of its critical, investigative coverage. With respect to political aims, it did not displease La Jornada's journalists that the targets of their criticism were at the opposite end of the political spectrum ideologically.

Information in the political and economic spheres may still be newsworthy without contributing to democratic journalistic aims. For example, sensationalist crime coverage may sell newspapers without making the connection between crime and failures of the state, or an interview with a politician whose ideology aligns with the newspaper might be exclusive but not contribute information relevant for effective democratic governance. But some information that meets political or economic aims without technically being considered newsworthy may also end up in print. For example, celebrity gossip can be nonnewsworthy but financially beneficial information. Coverage of newspaper owners and their cronies, such as the example one journalist gave me about her story on the launch party for a new hospital attended by her newspaper's owner, can be politically useful without being newsworthy. At this journalist's newspaper, the latter type of story is referred to as a debe, which literally means a debit, and they are non-negotiable assignments - as if reporters owe it to their bosses to cover them.
In sum, this model provides a way to think about how reporters go about choosing the information (whether news or not) with which to populate the headlines. Of course, the model for each actual newspaper differs from this generic representation depending on the newspaper's editorial lines, and the aims of these editorial lines reflect individual economic and political contexts. The conceptualization of newsworthiness, however, is remarkably stable across newspapers. In the next sections, I take a closer look in turn at the characteristics of news determination criteria at Mexican newspapers with particular reference to implications for the publication of human rights information.

\section{Determining the newsworthiness of human rights information}

When I asked journalists in interviews what news is, and in particular what human rights news is, they usually hemmed and hawed before tentatively embarking on an answer. That journalists cannot easily describe how it is that they determine newsworthiness, the activity that dominates their working days, is a phenomenon of much interest for media sociologists. In their research on crime reporting, for example, Hall et al. state that though news values are 'widely shared,' they are 'nowhere written down, formally transmitted, or codified' $(1978,54)$. Or, as Barnhurst $(2005,261)$ so cleverly puts it, 'journalists acquire a nose for news, but they cannot describe its smell.' My interviewees expressed similar attitudes toward news judgment, using vague words such as 'ethereal,' 'uncertain,' '[based on] intuition,' 'a sentiment,' 'improvised,' 'arbitrary,' and 'subjective.' In the midst of discussing newsworthiness, one editor at La Jornada introduced me to a colleague who walked into the room as '[she who is] trying to understand that which cannot be understood.'

This lack of 'formal rules' about 'how they [journalists] impose order on flux' can perhaps be unsettling for outside observers like Rock, who argues that 'such a lack of structure creates a great potential for anarchy' $(1973,74)$. The academic question that arises is thus how it is possible that the front pages of different newspapers, without any prescribed protocols, often closely resemble one another. Just because newsworthiness rules are not formalized, however, does not mean they do not exist or cannot be learned (in contradiction to Rock's [ibid.] statement that news is 'governed by an interpretative faculty called "news sense" which cannot be ... taught'). They represent what Bourdieu (Bourdieu and Wacquant 1992, 128) calls 'practical knowledge,' which 'explains that the agent does what he or she "has to do" without posing it explicitly as a goal, below the level of calculation and even 
consciousness, beneath discourse and representation.' Just because individuals cannot formulate their 'practical knowledge' does not mean it does not exist. Journalists were very clear that news judgment was a skill and one that they had to pick up on the job. As a relatively novice reporter explained it: 'You need to learn to look for it, you need to know what the article is, you need to have the journalistic touch to say, "This is the interesting thing here, this is what can be taken out, squeezed, and exploited to make the article." I understood the importance of experience firsthand when one of the editors sat me down with a list of that day's articles and asked me to pick some to draw up a mock front page. I did, and my results were significantly different from what the editors had chosen. It was clear then to me that, as Tuchman $(1972,672)$ put it, 'news judgment is the sacred knowledge, the secret ability of the newsman which differentiates him from other people.'

News judgment's very lack of concreteness may be its greatest strength. As Jenkins (1992, 71) explains, paraphrasing Bourdieu, 'imagine the impossibility ... of having "on file" a rule or prescription for every conceivable situation which one might encounter in routine social life.' Human rights information can exist in infinite manifestations - different victims, perpetrators, violations, causes, consequences, etc. - and can coexist with an infinite variety of information on other topics, so to construct a fixed set of rules for relative news hierarchization would be impossible. The determination of newsworthiness must be improvisational, an attribute of this type of knowledge reflected in Thompson's (1990, 148) description of it as 'flexible schemata.'

In spite of newsmakers' insistent and persistent vagueness about their noses for news, their newsworthiness criteria eventually emerged during the course of our interviews, aided by discussions about particular human rights stories. First, human rights news is - as journalists ruefully acknowledged - usually about their violation. These newsmakers were rueful mostly about the state of human rights in their country rather than about the state of journalism's morbid preferences, although one editor did say, 'Unfortunately, we live off of bad news.' As the editor-in-chief of La Jornada explained when I asked him what a good human rights article was:

The best story would be no story - when you don't have to write about the violation of human rights. I suspect that we are many years away from this good article, this marvelous article. All the rest depresses me. Every article that we do on the violation of human rights is a catastrophe for us because it speaks of the brutality of a system. There is no good article about human rights - they are all horrible. Our obligation, like any media, is to publish it. The good article is the day when you don't have to do an article on this because the violation of human rights has ended. The day that the human rights defenders disappear, that will be the article of ocho columnas [eight columns]! ${ }^{4}$ Then we will be speaking of a society - a world - that is more in accordance with what it should be.

A journalist echoed this sentiment when he speculated that the reason that human rights reporting in Mexico focuses on the violation rather than the respect of human rights is because their violation is more prevalent than the respect for them. It also is more compelling, as one human rights reporter explained it, stating that a story about the military destroying houses in a community is just more interesting and 'tells us more' than the story of an NGO and the government signing an agreement. Besides their prevalence and intrigue, human rights violations are newsworthy because, as an editor at El Universal explained it, 'human rights are there to be taken care of ... Therefore it is news when they are violated.' His colleague at La Jornada echoed these sentiments, saying that 'speaking of breaking a human right is speaking of breaking society and of the social contract being broken.' These human rights journalists are not alone in their rationales for focusing on the 'bad' of human rights news; Hall et al. $(1978,68)$ explain the prevalence of crime news, and particularly of violent crime news, as attributable in part to the fact that 'violence represents a basic violation of the person ... Violence is also the ultimate crime against property, and against the state. It thus represents a fundamental rupture in the social order.

In tandem with the fundamental characteristic of human rights newsworthiness as being about violations, journalists search for information that is characterized by as many of the following features as possible: novelty, exclusivity, impact, representativeness, and timeliness. Novelty, as an editor at La Jornada described it, refers to 'information on something you don't know about.' Exclusivity is valued not only for the 'scoop' factor but also for its shelf life, which lasts as long as the information can be kept from other media. This relatively long shelf life means that the exclusive article is valuable for the flexibility it gives editors in planning their pages.

Journalists think about impact in several ways. Several mentioned the importance of political impact, especially in the context of an avowedly political paper such as La Jornada. Given that human rights 
news almost always involves a governmental authority accused of a violation, it inherently has a political impact, though the scale of that impact can vary depending on the accused or on the type of accusation. Newsmakers also measure impact according to the scale and/or severity of the violation. Usually, a human rights situation is deemed newsworthy if it involves multiple victims (the most-cited examples of this were Mexico's Dirty War and the 2006 Atenco conflict), though exceptions are made in cases with a single victim when the violation was considered severe. For example, one journalist mentioned Paulina Ramírez's case, which went to the Inter-American Commission on Human Rights. At the age of 13 , Paulina became pregnant as the result of a rape. State officials illegally denied her right to an abortion. This journalist considered Paulina's case newsworthy because of the age of the victim, the 'adding insult to injury' aspect of the violation, and the nature of the human rights violation itself.

Single-victim violations can also be valuable in terms of newsworthiness if they are representative of a wider phenomenon. In one journalist's words, a newsworthy story has 'sufficient elements to represent or crystallize an activity or a way of being that is repetitive and continuous on the part of the authorities, that is not restricted to the individual complaint but that is representative of a real problem that is repeated.' Human rights stories about particular victims provide a way to vividly illustrate these problems. An editor at El Universal gave me the example of how his 'Society and Justice' section thus treated a report about gender inequality across Mexico:

There are two ways of publishing this information. The day that the report is presented, you can say, 'Chiapas is the least equal and the Federal District is the most,' and that's it - and include a graph. But what we did was look for a story of two women and to talk about it through people, so that tomorrow, when people read it, women will identify with one or the other woman ... If you present the numbers, they will rapidly see that there is a great inequality. But these figures won't stay in their heads over time. The idea is this - that when we talk of inequality or poverty, people have a point of reference ... The image of the woman comes to their head.

The more timely a human rights story is, the more newsworthy journalists see it as being. They refer to such a story as having 'conjuncture' (coyuntura) because of its relatedness to current events what journalists in the US often call a 'news peg.' This requirement of conjuncture can be frustrating for journalists at times, as it can keep information that is unrelated from current events but nonetheless considered important out of the news.

Journalists see newsworthiness as a relative rather than an absolute concept, which means, as one editor put it, that the same news could be front page today but in the interior pages tomorrow, based simply on what else happens that day. Schlesinger $(1987,57)$ explains this well with reference to the ranking of information at the BBC: 'When the editors have found a story which they think is sufficiently newsworthy to head the bulletin, they have a yardstick against which to judge the newsworthiness of others.' Layered over this newsworthiness assessment is the assessment of how well information fits particular newspaper aims, which I turn to next, beginning with an exploration of Mexican newspapers' journalistic aims.

\section{Journalistic aims of human rights reporting: supporting democracy and stopping violations}

As mentioned above, journalistic aims refer to the ideal role that journalists see their media institution as playing in society; for many journalists, such as the change agents in the Mexican media sphere, the media should aspire to practicing democratic journalism focusing on, among other goals, generating accountability and supporting pluralism. Democratic journalism was the original mission of Mexico's fledgling market-oriented newspapers, so it is no surprise that democratic journalistic aims were 'top of mind' for journalists when I asked them to describe their editorial lines. At La Jornada, for example, journalists explained their aims as including 'giving voice to those who don't have it' and 'criticizing power.' El Universal has a Code of Ethics encapsulating these ideals with phrases such as: 'All activities of the media and of journalists should be inspired by the public interest, keeping in mind that pursuing any private interest in the transmission of information is contrary to the principles guaranteed by the Universal Declaration of Human Rights.' Like talismans for democratic journalism, dog-eared copies of this Code of Ethics nestled in journalists' pockets and adorned their desks.

Complementary to its Code of Ethics, El Universal has a special agenda of topics that one editor described as addressing 'the basic principles of democracy.' He explained further: 'The country we live in has poverty and discrimination, has millions of migrants, drugs, corruption. Faced with this, what the paper has to do is tackle these problems. We are convinced this is what we should do.' The topics on this agenda, which editors must ensure receive particular attention 
in their sections, include the problem of human rights in Mexico. In fact, at several newspapers, resources are devoted to human rights reporting in part because it is a surefire route to pursuing democratic journalistic aims.

Beyond the wide-ranging notion of these democratic journalistic aims, journalists have specific journalistic aims with respect to their human rights coverage. They outlined several concrete means by which they wished their human rights news to have an impact on their society. Human rights coverage can serve as a check against violations, journalists said, both through its publication and through its practice, namely both through bearing witness and through being witness.

In terms of bearing witness, journalists described a process where their human rights reporting makes them what one reporter called a 'counterpart' and 'counter-power' to the state. Human rights coverage can awaken a moral outrage in the public, journalists said, by, as one explained it, causing readers to think: 'How great that I am not in that situation. What can I do so that those people no longer live like that?' Clearly, one possible action for constituents is to put pressure on their elected officials, resulting in governmental action and thus achieving what Protess et al. (1992) would describe as the classic policy agenda-building aim of this type of journalism. If politicians themselves are readers, journalists hope that human rights coverage could also appeal to their humanity directly and stir them to act. As one journalist described it: 'It has to be a daily battle - opening spaces in the media and the national debate, putting it [human rights] on the candidates' agendas.' In so doing, as one editor explained it: 'I think that here we fulfill one of the roles of journalism - ... ensuring that institutional machinery functions.'

Journalists recognized that they have a vital partner in this function, and one that equally depends on them: the human rights community (though this relationship is often fraught; see McPherson 2010). Journalists spoke in particular of their duty to work with Mexico's human rights commissions by publishing their recommendations for redressing human rights violations issued to infringing institutions. As one journalist described it:

The force of all the human rights commissions in Mexico is the public denouncement because they don't have the possibility to sanction. For them, it is the moral power. So when they generate a recommendation, what we do is publish it, because we understand the work of the human rights [commissions]; they do their part, and we do our part when we publish their recommendations.

Another journalist described this partnership in a similar manner, emphasizing the singular importance of the media in holding the state accountable through the generation of public moral pressure:

The blacklist of authorities who don't comply with the commission recommendations is an important article because that is the name of the game. The human rights commission morally pressures the [governmental] institution, but if the media doesn't pick up this moral pressure, the institution says, 'Well, nothing happened, the Commission said that I didn't fulfill [the recommendation] ... but nothing has happened [to me] ...' But if [the commission] says it and ten newspapers publish it, Amnesty International might find out, [and the institution] feels pressure to fulfill. This is how it works. If the people don't find out because we don't publish - if no one finds out, the authority just says, 'Whatever.' Moral pressure is how this system functions because the commissions cannot legally oblige authorities to obey.

The media's ability to stop human rights violations does not only rely on pressure generated by publication; it can also occur via faceto-face monitoring as well. The physical practice of covering human rights - being witness - is a powerful tool for stopping human rights violations, journalists said. In essence, the threat of the media's coverage is enough to prevent violations from occurring if that coverage is guaranteed. One editor described this phenomenon with respect to one of 2006's biggest human rights stories in Mexico. He refers to this story in shorthand as Atenco, the name of the town where a clash took place between police and a crowd supporting the street vendors the police were trying to relocate, resulting in serious casualties on both sides:

For example, everyone is aware of the issue of Atenco. It was televised. Lots of human rights were violated. But if there had not been live television coverage or live photographers, I think there would have been more deaths - because they would have acted without anyone watching.

The media's presence is not always an antagonistic act toward the government, positioning a defender of democracy and the people against a violator of human rights. It can be a symbiotic event, where the media get their story, the people are protected from violations, and Mexico's post-transitional state can burnish its democratic image as a respecter of human rights. As this editor went on to explain: 
So now in many police operations ... like relocations, they invite the National Human Rights Commission. They say, 'Accompany us so that you see how we are going to use force, because the state has the privilege or the obligation to use force when it is necessary, but we are going to use it adhering to the respect of human rights. We are going to remove them, but we are not going to hit them or kill them or wound them.' So they invite the Human Rights Commission and often they invite the media, so the media are witnesses. And they do this precisely to avoid being accused of human rights violations.

It seems that the media's presence has had this sort of effect only since it has put an end to its relationship of cronyism with the state. As one reporter described it: 'Before, it was very common that the police hit people in front of us journalists. With the advancement of the media, the government has been obliged to train its police ... They don't do it in front of witnesses, but it still happens.' An editor concurred: 'Unfortunately, when they have planned on violating human rights, they don't invite the Commissions or the media.' As such, this effect is limited to potential violation triggers that the media know about. Furthermore, as a journalist pointed out, it is also limited to particular categories of rights. As one journalist said, the government may have 'its hands more tied with respect to these rights, but it is harder to go and document the rights to health and housing.'

Journalists did not just hope to be able to protect rights on their own or in collaboration with human rights organizations, but also by empowering the citizenry. They felt that their coverage has an important educational aspect. When I asked them about their aims for their coverage, several mentioned that they wrote about human rights with the aim that their readers 'learn that they have rights.' Beyond informing for information's sake, journalists hoped that the public would deploy human rights knowledge to their advantage in their relationship with the state. As one said, 'If people know their rights, they can organize to defend them or even just to demand that they be respected,' and, as another said, so armed, the public 'themselves can defend their integrity, their citizenship, their lives.' By implication, the idea is that the citizenry does not have to wait for a human rights organization or the media to come to their rescue.

Journalists like the fact that their human rights reporting can reverberate beyond the page in these ways particular to this type of coverage - that, as one reporter said, it can change a situation, no matter how small. A few journalists called this 'transcendence,' a concept that, self-consciously or not, seemed to be a loose interpretation of the Horkheimer and Adorno (1979) idea based around the same word - the notion that a cultural form can create a moment in which the observer of that form transcends reality and can achieve a critical stance that can fuel change. As one human rights reporter explained it:

This beat ... allows you to make contributions that you couldn't as much in the political section. When you denounce that someone's rights were violated, they may get help or rise above the situation. This is why I like the beat so much - that it does not just stay a denouncement. People can benefit from you, whereas not so much from the political section, which is only what the politicians declare. It doesn't go beyond the declaration.

Some journalists called their human rights reporting an act of consciousness-raising, while others considered it a form of activism or almost-activism. As one reporter described it: 'What happens to a lot of us working on this beat is that we feel that ... we have to do more than just inform; rather we must participate in the defense and the promotion of human rights.' No doubt the fact that some reporters' career paths move back and forth between employment by media companies and employment by human rights organizations normalizes the blurring of boundaries between journalism and activism. Not all journalists were comfortable with this tendency, however. One reporter said: 'I know people who are obsessed with the topic and sometimes lose the distinction between their work as reporters and their militancy for human rights. You lose objectivity and you give priority to things that may not be certain or people who aren't right.' But most reporters seemed to feel that they were productively operating somewhere between the two practices; as one reporter described it, 'it is not exactly that we are doing militant journalism, but generally it is about making denouncements.' As another put it, 'rather than being a protagonist, the journalist is a mediator between the public and political and social actors.'

Overall, then, journalists involved in human rights reporting at Mexican newspapers see their coverage as both fulfilling their general democratic journalistic aims and meeting particular journalistic aims related to acting as watchdogs against power abuses and serving the public. As one journalist aptly summed it up: 'This is news that serves two things: informing and preventing. Inform the competent authorities so that they work in favor of justice. Prevent the next generations from the same errors.' Given this multilayered emphasis 
on the journalistic aims of human rights reporting, we can imagine that the journalistic aims sphere is deeply shaded in the news determination framework for human rights reporters. It may even, at times, extend beyond the boundaries of newsworthiness. As one editor put it, 'what we are looking for - more than newsworthiness - is that it [the violation of human rights] doesn't happen anymore.' At the newspapers where human rights coverage is a priority - namely, market-oriented newspapers - the newsrooms' overall news determination framework matches that of these journalists. Furthermore, as we will see below, the human rights news that falls within the journalistic aims category is often reinforced by newspapers' economic aims. However, at state-oriented newspapers, the newsroom's news selection framework often clashes with that of the human rights reporter because of the importance of newspaper owners' economic and political aims, which often contraindicate human rights coverage.

\section{Economic aims of human rights reporting: meeting reader demand and filling column inches}

Most Mexican newspapers were quite concerned with their economic aims, which varied according to whether they were financially market-oriented or whether they depended on sponsors from the political classes. Market-oriented newspapers faced growing competition from electronic media for a private advertising market constrained by Mexico's status as an emerging economy as well as by a limited audience size. Despite adult literacy rates above 90 per cent (United Nations Development Programme 2007), Mexico is characterized by what one editor called a 'culture of not reading.' Furthermore, newspaper prices can be prohibitive; a newspaper can cost about one-quarter of the minimum daily wage. As a result, newspaper circulation in 2000 was 93 per 1,00o inhabitants - less than half that of the United States (UNESCO Institute for Statistics 2011). State-oriented newspapers had to continually curry the favor of their sponsors or risk perishing, as market alternatives are even more constrained for regional newspapers than for their national counterparts. The context-influenced variety of economic aims of a newspaper largely determines how much its economic aims overlap with journalistic aims, and therefore how influential economic aims are in determining human rights news.

For market-oriented newspapers, overlap between economic and journalistic aims with respect to human rights news corresponds with the extent to which journalists see their readership as interested in human rights stories. Although some newspapers did track reader- ship demand through surveys and hit rates on the web versions of their newspapers, journalists' understanding of their readers was not always grounded so much in data as in feeling. Readers were perceived as interested in human rights news for several reasons. First and foremost, journalists at market-oriented newspapers conceive of their audiences as, like them, interested in information relating to democratic governance. As one editor said, 'the violation of human rights is frequently among our articles, and the paper gives it space, because it sells. People want to know. If someone was beaten, if their rights were violated, people want to know about it - yes, it is news.' His colleague at another newspaper echoed this sentiment, saying that the middle- and upper-class readers his newspaper targets are very interested in human rights coverage, as 'they are interested in the law being respected, that the authorities don't abuse [it].' This perceived interest is a very strong driver of human rights coverage at some newspapers - as long as the demand is seen to last. Journalists who had previously worked at Reforma, a right-leaning national newspaper targeted at Mexico's economic elite, told me that readership research there revealed a relative lack of interest in human rights among readers, perhaps because Reforma's relatively privileged readers are so infrequently the victims of violations. Coverage was decreased accordingly. It is not that human rights do not matter to Reforma, one ex-employee said, but rather that they became seen as the relatively dispensable pieces of news in the information hierarchy, given lackluster reader demand; in other words, this shift in reader demand meant that human rights news was no longer so heavily populating the overlap between journalistic aims and economic aims for Reforma.

Beyond its content, market-oriented journalists see their readers as interested in human rights news for what it conveys and conjures. Particular types of human rights news, they believe, can generate emotional reactions in readers that draw readers to the newspaper in question. This includes a feeling of affiliation important for gaining and retaining audiences. One national Mexican newspaper wished to shore up its numbers of female readers and young readers, whom the directorship viewed as being especially concerned with situations of injustice and with human rights violations in particular, since they are the sectors of Mexican society vulnerable to violations. The directorship saw human rights reporting as capable of generating stories to which women and youths could relate because similar things had happened to them, to people they knew, or to people like them. This tactic, while encouraging certain types of human rights coverage, may also 
limit other sorts, such as coverage of violations committed against other vulnerable populations less likely to buy newspapers, including the elderly or indigenous.

Another emotional reaction among readers that journalists attribute to human rights coverage is that of titillation, the province of tabloid-style journalism. In Mexico, one of the most popular forms of tabloid is nota roja, practiced predominantly by its regional and popular newspapers. Nota roja is disturbingly graphic, featuring photographs of decapitated bodies, terrible accidents, and abused victims; these photographs are so horrific that, for example, nota roja newspaper $L a$ Prensa's website, featured, for a period, a disclaimer that popped up when one navigated to its homepage, warning: 'The content of this site could be considered not appropriate for minors and for sensitive people. Do you want to enter?' Particular categories of human rights stories - 'the most bloody, those that have to do with rapes of women, sexual violations, deaths, murders,' in the words of one reporter - are prime candidates for nota roja coverage and are therefore pursued avidly by newspapers that practice this type of journalism. Of course, the particular economic aim of attracting readers via nota roja journalism has the effect of circumscribing the human rights information that meets both journalistic and economic aims, potentially excluding non-violent violations such as the denial of rights to education and health care.

A third economic aim of human rights coverage is related to what it conveys about its newspaper: credibility. Given the tradition of the cozy state-media relationship in Mexico, which persists in many pockets, market-oriented newspapers are continually interested in proving their credibility with respect to independence from the state. Their journalists see this credibility as key to attracting readers, as illustrated by a story told by an editor at a newspaper in Oaxaca transitioning from state- to market-orientation. A local tae kwon do champion had been beaten by the police 'like Rodney King' and then taken to the jungle, where he died from his injuries. Members of the police set up the scene of his death to look like suicide, but, following a long court case, they were eventually convicted. This editor said his newspaper covered the story in part because:

We are a new paper that aspires to credibility, a higher circulation that wants to gain the confidence of the people. This article brings credibility because it converts us into a trustworthy media. Tiempo tells the truth. Tiempo doesn't hide things. They say, 'Well, Tiempo defends the interests of society. It is playing the role it was given as a paper: denouncing abuses so that they are solved, so that the authorities create order.' So, this gives us credibility.

Conceivably, even readers uninterested in human rights may become loyal readers of a newspaper that covers human rights, not for the information this type of story contains but for what it connotes about the credibility of the rest of the information in the newspaper. Like reader interest related to democratic information, affinity generation, and tabloid titillation, this perceived demand maintains an overlap between journalistic and economic aims related to human rights coverage at market-oriented newspapers as long as the demand continues - or at least continues to be perceived. The framework is very different, however, at state-oriented newspapers, where financial concerns often make the spheres of economic and journalistic aims look less like a Venn diagram than like a game of marbles.

Much of state-oriented newspapers' incomes derive from financialinformational contracts with individual politicians who want to, in the words of one journalist, 'buy protection.' Protection comes in several forms. For example, politicians can buy 'ad articles,' where a reporter is commissioned to cover a particular political story in a particular way; they can purchase a guarantee that all their press releases will be published; and they can rent a prominent news space to publish whatever they please, including discrediting information about their opponents. The newspaper's end of the bargain boils down to excluding the bad news and including the good news about paying politicians and their cronies, and vice versa for their political opponents. Traditionally, journalism in Mexico operating in this fashion was a lucrative endeavor, and economic goals remain paramount for many journalists and owners at contemporary state-oriented newspapers. One reporter in Chiapas explained his boss's perspective on news selection in the following way:

For example, if I was the owner of a newspaper ... and a denouncement arrived concerning someone whose rights were violated, for me it's not news because it is not useful to me. I don't obtain anything from it ... for my economic interests. So it is better that I omit it and use the space for something that really will benefit me. I think this is the logic of the newspaper; for this reason there is no diffusion of human rights violations.

In the upper echelons of news decision-making, therefore, economic aims may entirely eclipse democratic journalistic aims. 
Despite this, human rights coverage can slip into the pages of stateoriented newspapers, largely under the aegis of individual reporters for whom these journalistic aims are a priority. Of course, this coverage must adhere to these newspapers' financial-informational contracts, so stories accusing paying politicians and their pals of human rights violations are taboo. Outside this restriction, however, concerned reporters can publish human rights stories because they can serve an important function for the state-oriented newspaper: filler. With reference to market-oriented media outlets in the United States, McManus (1994, 124) describes a type of information as 'hamburger helper,' in that it serves as filler, rounding out the newspaper once the meat of information meeting journalistic and economic aims has been selected. In contrast, informational filler at state-oriented newspapers in Mexico - where it is known as 'chorizo' because it is assessed not so much by its content as by its length - is any information not directly related to financial sponsors, including information that one might consider emblematic of democratic journalism.

Whether human rights information makes it into the news depends, therefore, on which politician or agency is the target of the accusation. For example, a reporter in Chiapas told me that his newspaper 'has an unwritten pact that you have to look after the governor,' but that he could write about the human rights violations committed by 'the rest [who] don't matter,' namely, state employees and entities that, unlike the state executive's office, do not have enough funds in their budgets for advertising contracts. These stories included the abuse of street children, discrimination in the classroom, rape allegations levied against teachers, and the situation of women in Chiapas. Another reporter told me that her articles criticizing the legislature are often published, even on the front page, because that governmental body cannot afford to pay newspapers, even to get the legislative agenda published.

The content of state-oriented newspapers, therefore, is often determined by multiple news selection frameworks, with economic aims more important among those at the top of the newsroom hierarchy and journalistic aims more important among those at the bottom, the reporters. These reporters are very careful to respect the limits of tolerance for democratic journalism, though, as they may face dismissal for crossing the line, not to mention legal and physical recriminations from disgruntled targets of their coverage. As one reporter said: 'There are many newspapers that prefer to sacrifice their reporters than to lose advertisements.' Differences between individual news selection frameworks within one newsroom - where hierarchy trumps - are not, however, confined to state-oriented newsrooms. I witnessed the same at market-oriented newspapers, though to a lesser extent. There, journalists would gift unpublished stories they thought newsworthy and journalistically important to colleagues at other media outlets as a way to circumnavigate the restrictive aims of their superiors: 'You have to make information flow, and even more when it concerns things that need to be denounced,' said one reporter in describing this practice. Besides economics, another area in which editors and reporters clash at times is the type and prominence of newsroom political aims.

\section{Political aims of human rights reporting: limited partisan and personal motives}

A lot of what seems political in traditional Mexican journalism the pandering to one party accompanied with ferocity toward another - is actually economic in nature. Purely political aims are therefore relatively minor compared with economic aims in terms of their importance in determining news selection. Political aims that do exist at Mexican newspapers fall into two camps: partisan political aims and personal political aims.

Some of Mexico's biggest market-oriented newspapers are openly - even avowedly - partisan to a particular political perspective. La Jornada, for example, is aligned with the political left. Under a conservative government, it is not difficult for its newsroom to line up its political aims with its journalistic aims of speaking truth to power. Although many journalists there stated that their political aims were ideological rather than party-based and that their critical stance would persist should the left rule in Mexico, others were not so convinced. 'This is the challenge the paper faces,' one reporter there told me: 'Not to forget that this human rights denunciation has to continue no matter which party the government is.'

Personal politics can also play a role during both state- and marketoriented newspapers' news deliberations. These are instances where an editor's or owner's personal ambitions or relationships may affect the information covered by their newspaper - a situation magnified by the close social and professional circles of journalists and politicians in Mexico. For example, a journalist in Chiapas told me that one of his state-oriented newspaper's owners already holds a political position but hopes to move upwards in the local governmental bureaucracy. He therefore allegedly struck a deal with one of the candidates for state governor, promising his campaign favorable coverage in return for 
a coveted job should the candidate be elected. At a market-oriented newspaper, a journalist explained to me that coverage of ex-president Luis Echeverría's 2006 indictment for his involvement in a 1971 fatal suppression of student protestors - front page at many other newspapers - was limited to a photograph in the back, 'practically with the cinema listings,' because the owner of her paper is good friends with Echeverría. Although striking, overall this practice seemed to be quite limited, at least in comparison with the effects on coverage of trying to successfully operate a newspaper in a harsh economic environment.

\section{Conclusion}

In this chapter, I have shown that human rights news is the outcome of a news determination process where newsworthiness is assessed in concert with a number of newsroom aims that coexist under the umbrella of the editorial line. Human rights information must usually be about violation rather than protection to be considered newsworthy. Beyond that, the more novel, exclusive, impactful, representative, and timely it is, and the more it meets newspapers' journalistic, economic, and political aims, the more likely it is to be published.

For journalists who strongly subscribe to democratic journalistic aims and practice human rights reporting accordingly, a clear link exists between human rights news and activism. Journalists can be activists both by being witness, whereby their physical presence impedes violations, and by bearing witness, whereby their publishing of human rights information helps puts a stop to it. In the latter scenario, this information is intended to raise public awareness, leading to pressure on politicians, or to influence politicians as readers directly. In so doing, journalists often work hand in hand with human rights organizations, providing the access to audiences so necessary for generating public moral outrage. Human rights news can also be aimed at educating the public, so that citizens can act in defense of their rights on their own behalf. While some human rights journalists are comfortable calling their work 'activism,' others are wary of the blurring of boundaries between journalism and activism, fearing that it might compromise journalistic objectivity.

The journalistic aims that impel human rights reporting coexist alongside other aims - some countervailing, some reinforcing, and varying between and within newsrooms. Human rights coverage correspondingly differs. At market-oriented newspapers, human rights coverage receives a boost from its ability to dovetail with journalistic aims, which are relatively prominent in these newsrooms. It is also seen as helping to generate audiences through demonstrating newspapers' critical independence from the state and providing in-demand, democracy-enhancing information. Furthermore, particular types of human rights news are prioritized for their ability to attract particular audiences, including nota roja-style stories and information about violations targeting certain segments of society. Human rights coverage benefits from the pursuit of market-oriented economic aims, therefore, but only for as long as the readers are perceived as being interested in it. At state-oriented newspapers, human rights news may be prized by reporters for its content but by the directorship for its usefulness as filler. As long as it causes no trouble for financial sponsors of these newspapers, it may occupy column inches. Furthermore, at both types of newspapers, human rights news must be in line with partisan and personal politics when these political aims are salient.

The mechanics of the framework of news determination I have outlined in this chapter are as important for the news they include as for that they leave out. In addition to considering the effects of the media on human rights mobilization, we must remember the fact that a significant proportion of human rights information never reaches a public because it is not witnessed, it is not considered newsworthy, or it contraindicates the media's editorial line aims. The particular examples outlined in this chapter include human rights information concerning sectors that do not make up significant proportions of the readership, and, at nota roja newspapers, human rights information that does not involve bloodshed, for example coverage of health and education rights. These 'news silences' (Cottle 2007, 5) can have just as much of an effect on public opinion and policymaking with respect to human rights as can human rights news.

\section{Notes}

1 As part of my media ethnography, I interviewed 26 reporters and 26 editors at 16 of Mexico's marketoriented newspapers, headquartered in Mexico City, and state-oriented newspapers, located in Oaxaca and Chiapas, who held positions along the production chain of human rights reporting. Interviews were tape-recorded, transcribed, and translated by me. These interviews, supplemented by participant observation in the newsrooms of two of Mexico's largest market-oriented newspapers, La Jornada and $E l$ Universal, allowed me to parse the influences on human rights reporting at Mexican newspapers. ing my own definition of human rights reporting or of human rights on this research, I was guided by how my informants defined these categories - interesting data in and of itself.

3 Though not depicted in this
2 Accordingly, rather than impos- 
diagram, exceptions to this do occur. For example, one might be a Mexican newspaper's publication of the outcome of a children's drawing competition at the Federal District's Human Rights Commission - not a newsworthy piece of information, but one that, by maintaining human rights on the news agenda and educating the public about human rights, supports democracy. An editor told me that they publish every bit of information sent out by that Commission because he sees their work as intertwined - namely, the Commission relies on the media to generate the public pressure to prevent or stop human rights violations.

4 This is the Mexican equivalent of saying that the article will be placed 'above the fold' on the front page. Traditionally, Mexican newspapers had front pages with eight columns of text, so to say that the article gets eight columns means that it is considered important enough to be assigned all eight of the front-page columns.

\section{References}

Barnhurst, Kevin G. 2005. 'News ideology in the twentieth century.' In Diffusion of the News Paradigm, 1850-200o, edited by Svennik

Høyer and Horst Pöttker, 239-62. Gothenburg, Sweden: Nordicom.

Bourdieu, Pierre. 2007. Distinction: $A$ Social Critique of the Judgment of Taste. Cambridge, MA: Harvard University Press.

Bourdieu, Pierre, and L. Wacquant. 1992. An Invitation to Reflexive Sociology, 1st edition. Chicago, IL: University of Chicago Press.

Cottle, Simon. 2007. 'Ethnography and news production: $\mathrm{New}(\mathrm{s}) \mathrm{de}-$ velopments in the field.' Sociology Compass 1(1): 1-16.
Hall, Stuart et al. 1978. Policing the Crisis: Mugging, the State, and Law and Order. London: Macmillan.

Horkheimer, Max, and Theodor Adorno. 1979. Dialectic of Enlightenment. London: Verso.

Hughes, Sallie. 2003. 'From

the inside out: How institutional entrepreneurs transformed Mexican journalism.' Harvard International Journal of Press/ Politics 8(3): 87-117.

Hughes, Sallie. 2006. Newsrooms in Conflict: Journalism and the Democratization of Mexico.

Pittsburgh, PA: University of Pittsburgh Press.

Jenkins, Richard. 1992. Pierre Bourdieu. London: Routledge.

Lawson, Chappell. 2002. Building the Fourth Estate: Democratization and the Rise of a Free Press in Mexico.

Berkeley: University of California Press.

McManus, John H. 1994. MarketDriven Journalism: Let the Citizen Beware? Thousand Oaks, CA: Sage Publications, Inc.

McPherson, Ella. 2010. Human Rights Reporting in Mexico. Cambridge: Cambridge University Press.

Protess, David L. et al. 1992. The Journalism of Outrage: Investigative Reporting and Agenda Building in America. New York: Guilford Press.

Rock, Paul. 1973. 'News as eternal recurrence.' In The Manufacture of News: Social Problems, Deviance and the Mass Media, edited by Stanley Cohen and Jock Young, 73-80. London: Constable.

Rodríguez Castañeda, Rafael. 1993 Prensa Vendida: Los Periodistas y los Presidentes, 40 Años de Relaciones. Mexico City: Grijalbo.

Schlesinger, Philip. 1987. Putting
'Reality' Together: BBC News. London: Methuen.

Sikkink, Kathryn. 1993. 'Human rights, principled issue-networks, and sovereignty in Latin America.' International Organization 47(3): 411-41.

Thompson, John B. 1990. Ideology and Modern Culture. Stanford, CA Stanford University Press.

Tuchman, Gaye. 1972. 'Objectivity as strategic ritual: An examination of newsmen's notions of objectivity' American Journal of Sociology 77(4): 660-79.

UNSCO Institute for Statistics. 2011 'Daily newspapers: Total average circulation per 1,00o inhabitants.' Montreal: UNESCO Institute for Statistics. http://data.un.org.

United Nations Development

Programme. 2007. '2007/2008 human development report: Adult literacy rate.' New York: United Nations Development Programme. 